\title{
FRUIT AND SEED STRUCTURAL CHARACTERISTICS AND SEED DISPERSAL IN MERCURIALIS ANNUA L. (EUPHORBIACEAE)
}

\author{
MARCELLO LISCI AND ETTORE PACINI \\ Botany Section, Department of Environmental Biology, \\ University of Siena, Via P. A. Mattioli 4, 53100 Siena, Italy
}

(Received: July 1, 1997. Accepted: September 18, 1997)

\begin{abstract}
The fruit of Mercurialis annua L. is a two-seeded capsule with a caruncle, a small appendage which arises from the outer integument in the micropylar area. The inner integument has a thick layer of Malpighian-like cells, interrupted at the micropyle by a remnant of nucellus, the walls of which contain suberin. There is no cuticle covering the caruncle and its cells have lipids and protein bodies as reserves. Seed dispersal occurs by a combination of autochory followed by myrmecochory. The explosive ejection of seeds is caused by dehydration-induced torsion of the mechanical layer of the fruit walls.

This phenomenon is due to the different orientation of the cells and a folding over of the mechanical layer in the chalazal area. The seeds were found to be thrown distances from 1 to $130 \mathrm{~cm}$ (mean $41.1 \mathrm{~cm}$; modal peak $10-20 \mathrm{~cm}$ ). Ballistic dispersal is influenced by the weight of the seed. The seeds were collected by ants in a mean time of 24.4 minutes the maximum and mean distances of dispersal being 14 and $3.4 \mathrm{~m}$, respectively. Of the seeds removed, $95.2 \%$ were recovered on excavation of the ant nest. The seeds in the nest were intact but without the caruncles. The mean distance of dispersal by diplochory was $<5 \mathrm{~m}$. These features are discussed in relation to possible benefits to the plant species in terms of adaptive advantages of seeds.
\end{abstract}

KEY WORDS: ants, autochory, caruncle, Mercurialis annua, myrmecochory, seed.

\section{INTRODUCTION}

The distance a seed is dispersed from the mother plant depends on the dispersal agent (Howe and Smallwood 1982). Dispersal may be passive (when there are no facilitating anatomical structures), active (with the help of anatomical structures that favour dispersal) or induced (when anatomical structures encourage animals to disperse seeds) (van der Pijl 1982). Seeds are not only dispersed by vertebrates, but also invertebrates, especially ants (Sernander 1906). Many seeds collected by ants have an appendage known as an elaiosome (Fahn and Werker 1972). Morphologically, the elaiosome can be an exostomal or raphal aril, a caruncle or a chalazal outgrowth (Boesewinkel and Bouman 1984). This appendage contains reserves, usually lipids, but also proteins and starch (van der Pijl 1982, Lisci and al. 1996a). Evolutionary implications and adaptive advantages of myrmecochory have been studied extensively, especially in the Mediterranean-climate regions of Australia and South Africa (Berg 1975, Handel 1978, Culver and Beattie 1980, O'Dowd and Hay 1980, Beattie and Culver 1981, Heithaus 1981, Westoby and Rice 1981, Buckley 1982, Milewski and Bond 1982, Bond and Slingsby 1983, Turnbull and Culver 1983, Kjellsson 1985a, Kjellsson 1985b, Ohara and Higashi 1987, Hanzawa and al. 1988, Hughes and Westoby 1990, Andersen 1991, Bond and al. 1991, Hughes 1991, Gibson 1993 a, Gibson 1993 b, Aronne and Wilcock 1994, Cowling and al. 1994, Gabay and al. 1994, Nakanishi, 1994) and grouped into five categories: predator avoidance; fire avoidance; interspecific-competition avoidan- ce; nutrients in ant nests; dispersal for distance (Beattie 1985). Dispersal for distance is only regarded as a minor benefit of myrmecochory, because seeds dispersed by ants are not usually transported further than 10 metres (Beattie and Lyons 1975, Culver and Beattie 1978, Higashi and al. 1989, Gibson 1993a). This is a shorter distance than that covered by seeds dispersed by wind or vertebrates (Willson 1993). However, even short dispersal distances can reduce the competition between parent and offspring (Westoby and al. 1982) or can provide safe sites for seedling establishment, especially in arid habitats where microsites optimal for seedling growth are scarce (Davidson and Morton 1981, Andersen 1988, Westoby and al. 1991, Hughes and al. 1993).

Mercurialis annua $\mathrm{L}$. is a dioecious therophyte of wide distribution (Meusel and al. 1978). It is a common ruderal weed throughout Italy (Pignatti 1982) and also grows in synanthropic areas (Lisci and Pacini 1993). It mostly occurs in cultivated sites such as orchards and vineyards where the ground is frequently ploughed. Unlike many other species of the Euphorbiaceae that are pollinated by insects, $M$. аппиа is anemophilous (Lisci and al. 1996b). The period of flowering and seed maturation varies according to geographical location. In central Europe and northern Italy, it ranges from mid March to mid September, whereas in the Mediterranean countries including central and southern Italy the plant flowers and produces seeds more or less all year round (Charpin and Surinyach 1974). The seeds are actively collected by ants and carried away to the nest, germinating only when the nests are destroyed by ploughing of the soil (Pacini 1990). 

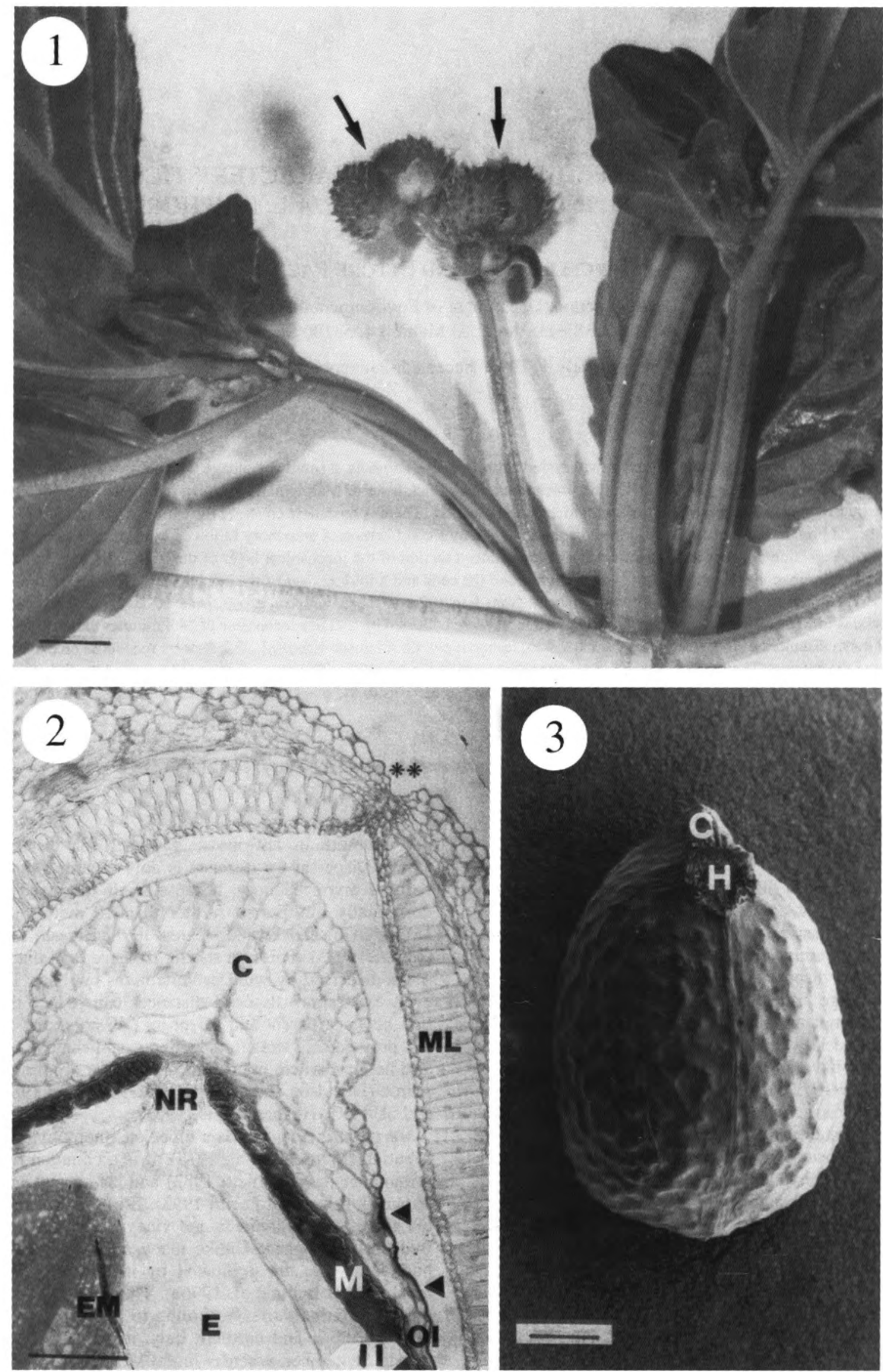

Figures 1-3. 1) Capsule of $M$. annua close to dehiscence. Arrows indicate the median septum. Bar $=1.5 \mathrm{~mm}$. 2) Section of an almost mature capsule of M. аппиа. Sagittal line of dehiscence (**); mechanical layer (ML); caruncle (C); outer integument (OI); inner integument (II); Malpighian-like cells (M); nucellar remnant (NR); endosperm (E); embryo (EM); arrowheads indicate cuticle. Bar $=60 \mu \mathrm{m}$. 3) Scanning electron micrograph ofa seed of $M$. annua. The caruncle $(\mathrm{C})$ is visible near the hilum $(\mathrm{H})$. Bar $=250 \mu \mathrm{m}$ 
M. апnиa is know to have different levels of ploidy and has been studied widely for the determination of sex (Durand and Durand 1985, Durand and Durand 1991, Louis and al. 1990). Recently, we investigated the pollination ecology (Lisci and al. 1994, 1996b) and germination of this species (Pacini 1990). In the present paper we report the results of a study of fruit and seed structure and seed dispersal of $M$. аппиа.

\section{MATERIALS AND METHODS}

\section{Light and scanning electron microscopy}

The general morphological characters of the fruits and seeds of $M$. аппиа were observed and measured under the stereo microscope. For light microscopy, the fruits and seeds were fixed in $3 \%$ glutaraldehyde in $0.066 \mathrm{M}$ cacodylate buffer, $\mathrm{pH} 7.2$ for at least $24 \mathrm{~h}$ at $4^{\circ} \mathrm{C}$. The samples were dehydrated through an ethanol series and embedded in LR White (London Resin Co. Ltd.). Semi-thin sections $(2 \mu \mathrm{m})$ were cut with an LKB ultrotome III and stained with toluidine blue 0 (TBO) for general morphology (O'Brien and McCully 1981). Lignin and suberin were detected according to Trockenbrodt (1994).

Caruncle reserves were determined by leaving the seeds to hydrate for $4 \mathrm{~h}$. The carundes were then removed using forceps and a sharp blade. The whole caruncle was then crushed on a microscope slide and stained with:

a) Sudan Black B for lipids (O'Brien and McCully 1981);

b) Lugol for starch (Jensen 1962);

c) Naphthol Blue Black for total proteins (Jensen 1962). The caruncles were also stained with Auramine O (HeslopHarrison 1977) for observation of the cutide.

Seeds required for scanning electron microscopy were placed on adhesive tape, attached to an aluminium stub. The samples were coated with gold (Edwards Sputter Coater model SA 150) and observed with a Philips 501 scanning electron microscope operating at $7.2 \mathrm{kV}$.

\section{Ballistic dispersal}

Explosive dehiscence of five capsules was followed with a video camera. Dehiscence was studied in slow motion and by observing the structure of the nearly ripe fruit. In order to plot a histogram of the distances reached by the seeds after explosive dehiscence, the following experiment was performed in May 1995. To eliminate the effects of wind, six female plants of different sizes were placed in a greenhouse in the centre of a sheet of plastic, 4 metres in diameter, previously coated with high viscosity silicon so that the seeds remained where they fell. Male plants were placed around the periphery to ensure pollination. After a period of two weeks weight of each seed was recorded, together with the distance dispersed.

\section{Field experiments}

The experiments were carried out in an abandoned field at Cappuccini, $3 \mathrm{~km}$ north of Siena ( $\left.35^{\circ} 12^{\prime} \mathrm{N}, 10^{\circ} 29^{\prime} \mathrm{E}\right)$, at an altitude of $280 \mathrm{~m}$, in June 1995 . One hundred seeds were marked on the testa with a spot of red nail varnish, ensuring that the caruncle was undisturbed. The seeds were placed randomly along a path followed by Messor structor (Latr.) ants, starting a few centimetres from the entrance of the nest. We recorded the time taken for the ants to collect the seeds.

To study the distance of dispersal by myrmecochory, we planted rigid plastic sheets in the soil to a depth of $20 \mathrm{~cm}$, to delimit a $20 \times 4 \mathrm{~m}$ area on a flat piece of ground. The purpose was to ensure that the "ant collectors" came from the same nest.

We checked that there was only one nest of Messor structor in the rectangle, situated near one of the shorter sides. Seven hundred and fifty seeds were again marked on the testa with a spot of red nail varnish, the caruncle was undisturbed. Groups of twenty five seeds, spaced at $1 \mathrm{~cm}$ intervals, were placed every $50 \mathrm{~cm}$, beginning at a distance of $0.5 \mathrm{~m}$ from the nest, in a northerly direction, continuing to a maximum distance of $15 \mathrm{~m}$. The seeds were positioned at $9 \mathrm{a}$.m. and the number removed was checked after 3 hours. Subsequently, the content of the nest was determined by carefully excavating the whole nest and removing an area of soil approximately $1 \mathrm{~m}^{2}$ to a depth of $50 \mathrm{~cm}$. The experiment was repeated in July 1995 .

\section{RESULTS}

\section{Fruit and seed structure}

The fruit is a capsule derived from a bristly, tuberculate ovary (Fig. 1), consisting of two lobes separated by a median septum (Figs 1 and 4A). The fruit wall has an external epidermis with stomata, an intermediate photosynthetic parenchyma and an inner mechanical layer (Fig. 2). The parenchyma contains fine vascular bundles. The mechanical layer consists of three layers of dead cells with lignified walls, namely two epithelial layers enclosing a palisade-like layer (Fig. 2). The mechanical layer is interrupted and folded over at the chalaza to form a lip (Fig. 4A). The mechanical layer is thinner along a median and a sagittal line (Fig. 4A), where fruit dehiscence occurs (Fig. 2).

The seeds are greenish-brown, elongated (1.5-2 mm) and ovoid in shape (Fig. 3). They have two integuments, the outer of which is a thin layer from which the caruncle arises. The carunde is a whitish micropylar appendage situated near the hilum (Figs 2 and 3). The epidermal cells of the carunde are without cuticle. The inner integument has two layers. The outer layer consists of a layer of Malpighian-like cells with heavily lignified and suberized walls. The inner layer surrounds the endosperm and embryo and consists of cells with thin pectocellulosic walls (Fig. 2). The two layers are interrupted at the micropyle by a remnant of nucellus, the cells of which have thin walls which react positively to the suberin test. The cells of the caruncle have lipids and protein bodies. The embryo contains starch reserves.

\section{Seed dispersal}

When a capsule is mature it is held away from the parental foliage on an erect peduncle (Fig. 1). As the individual valves of the capsule dry out, the seeds are ejected. Explosive dehiscence is due to dehydration of the fruit wall layers. This causes the mechanical layer to suddenly turn inside out, propelling the seeds from the chalaza in different directions (Figs $4 \mathrm{~B}$ and $4 \mathrm{C}$ ). Once the seeds are launched, the lobes of the capsule drop off.

The seeds are thrown distances from 1 to $130 \mathrm{~cm}$ (mean $41.1 \pm 31.3 \mathrm{~cm}$ ) with a modal peak between 10 and $20 \mathrm{~cm}$ (Fig. 5). After the peak, the relation between number of seeds and dispersal distance is negatively exponential $(r=0.90$, $\mathrm{P}<0.001)$ indicating that the number of seeds decreases as the distance they are launched increases. Between 20 and 30 $\mathrm{cm}$ the number of seeds dramatically decreases with increa- 

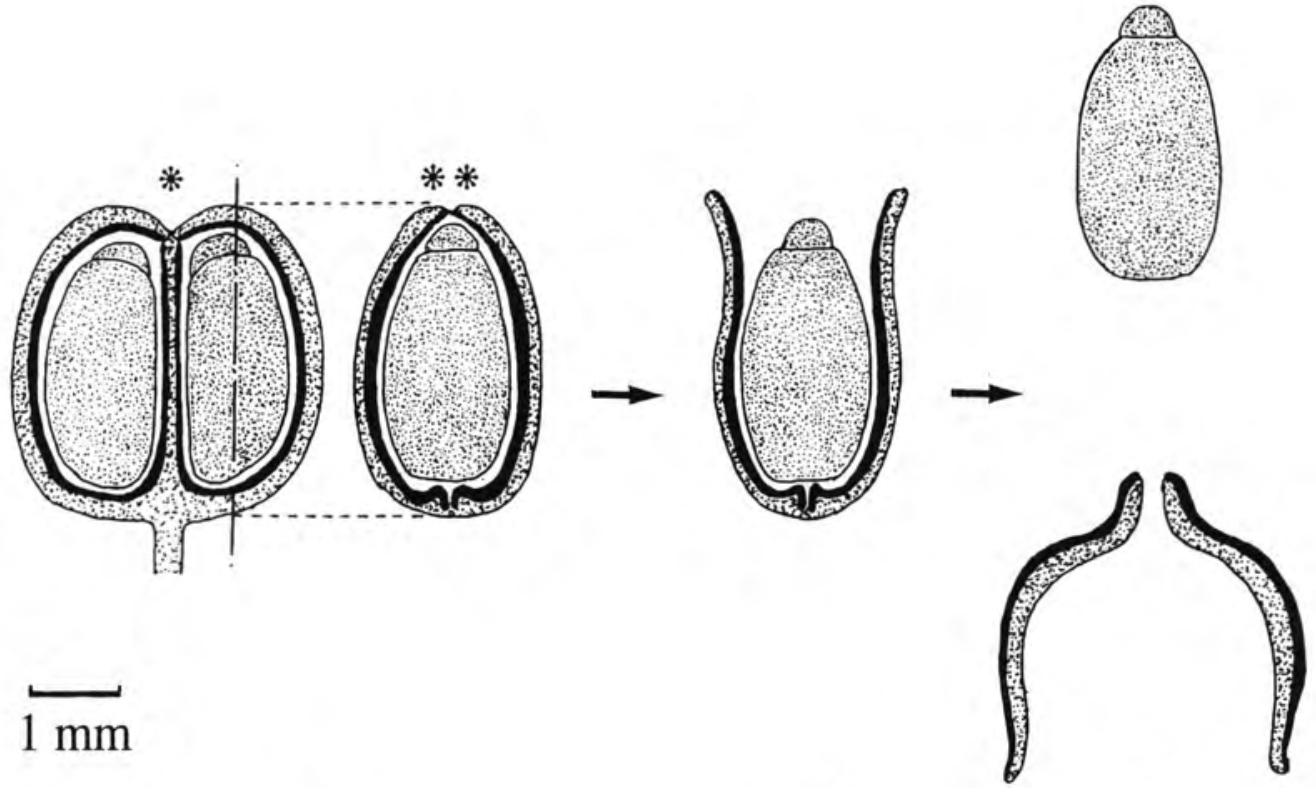

\section{A}

B

$\mathrm{C}$

Figure 4. Diagram of the stages of explosive dehiscence of the capsule of $M$. annua obtained from videorecording images and observation of the structure of the nearly ripe fruit. The mechanical layer is shown in black. A, frontal view of the capsule, showing the median dehiscence line $(*)$, and side view, showing the sagittal dehiscence line $(* *)$. B and $\mathrm{C}$, side view of capsule. The explosive ejection of seeds is due to the different orientation of the cells and a folding over of the mechanical layer in the chalazal area.

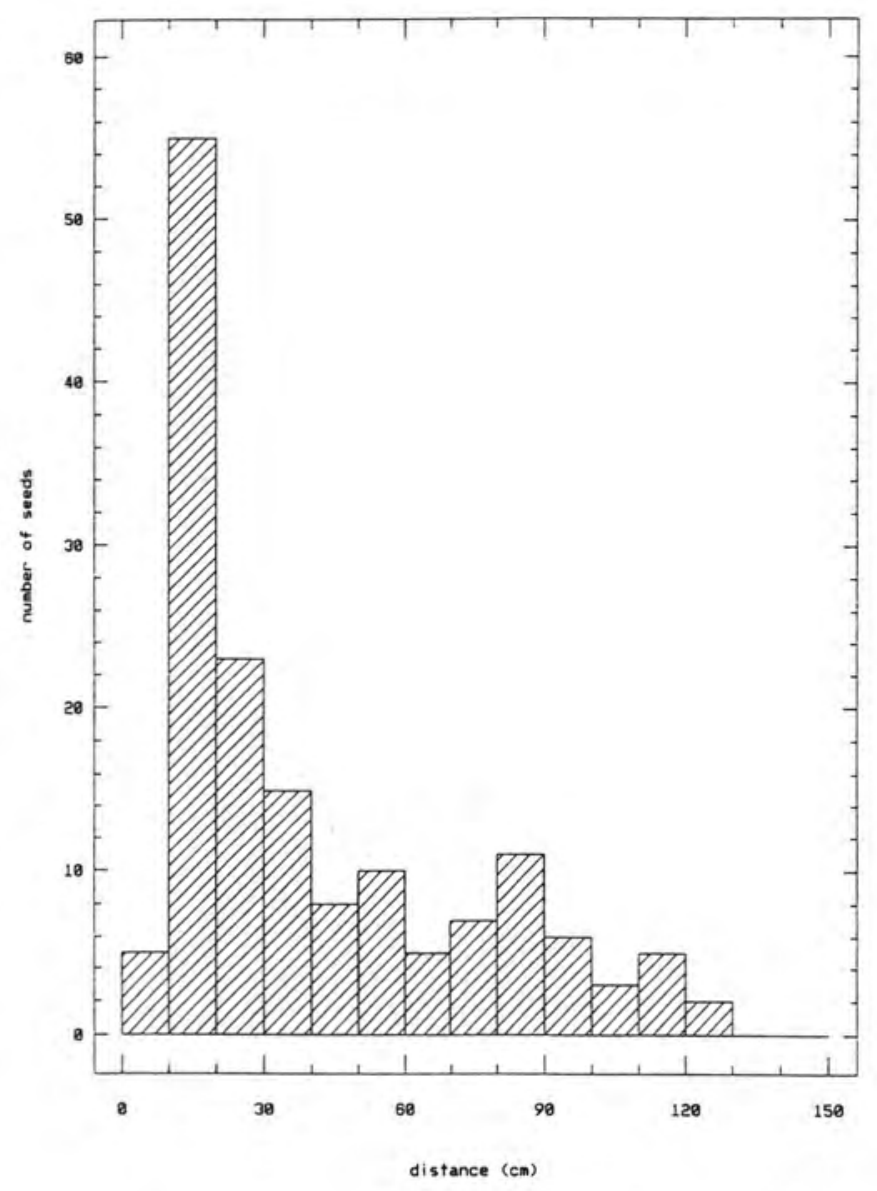

Figure 5. Frequency histogram of autochorous dispersal of seeds of M. annua $(\mathrm{N}=155)$. The seeds are launched up to $130 \mathrm{~cm}$ (mean $41.1 \mathrm{~cm}$ ) with a modal peak between 10 and $20 \mathrm{~cm}$.

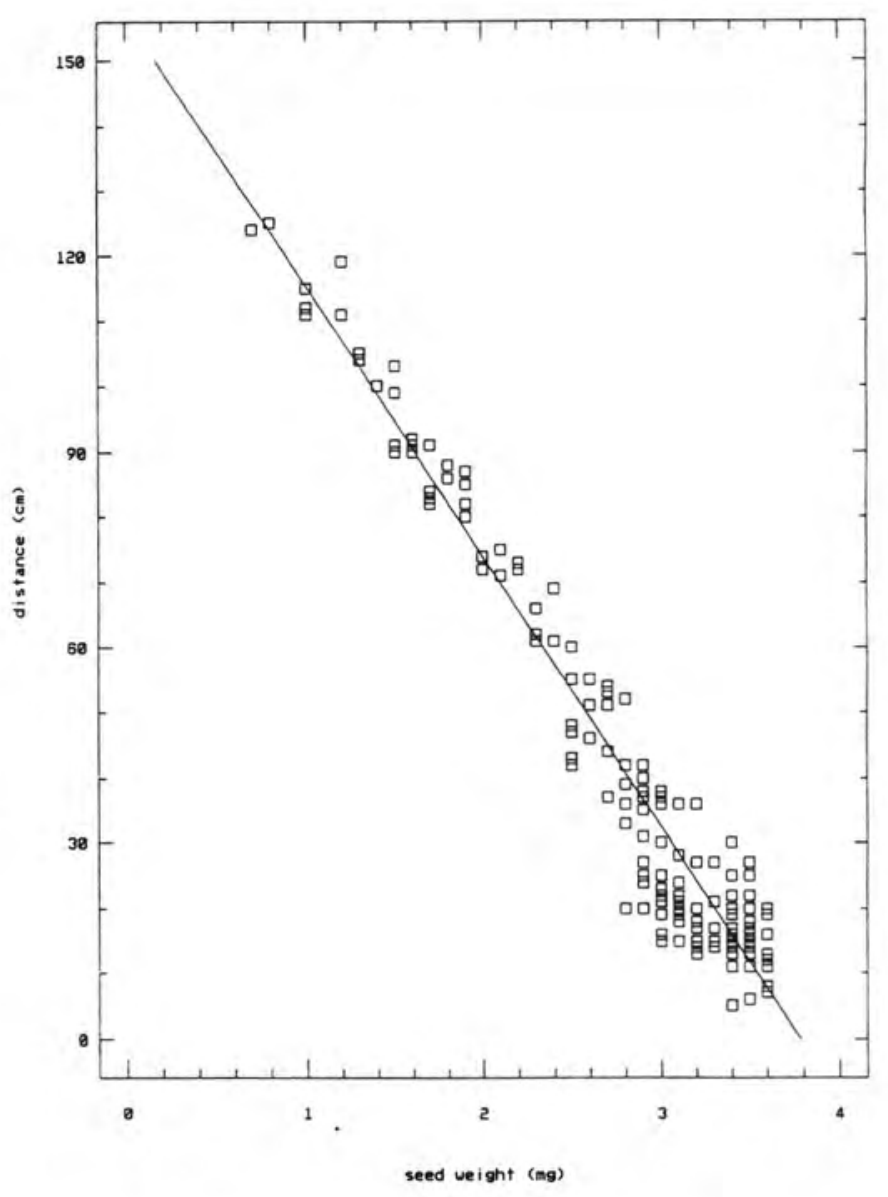

Figure 6. Simple regression between the distance of seed dispersal and the seed weight of $M$. annua. The equation of the regression line is $\mathrm{y}=156.9-41.4 \mathrm{x}, \mathrm{r}=0.97, \mathrm{~F}_{1} 1.153=2744.6, \mathrm{P}<0.001$. The distance is negatively related to seed weight. 


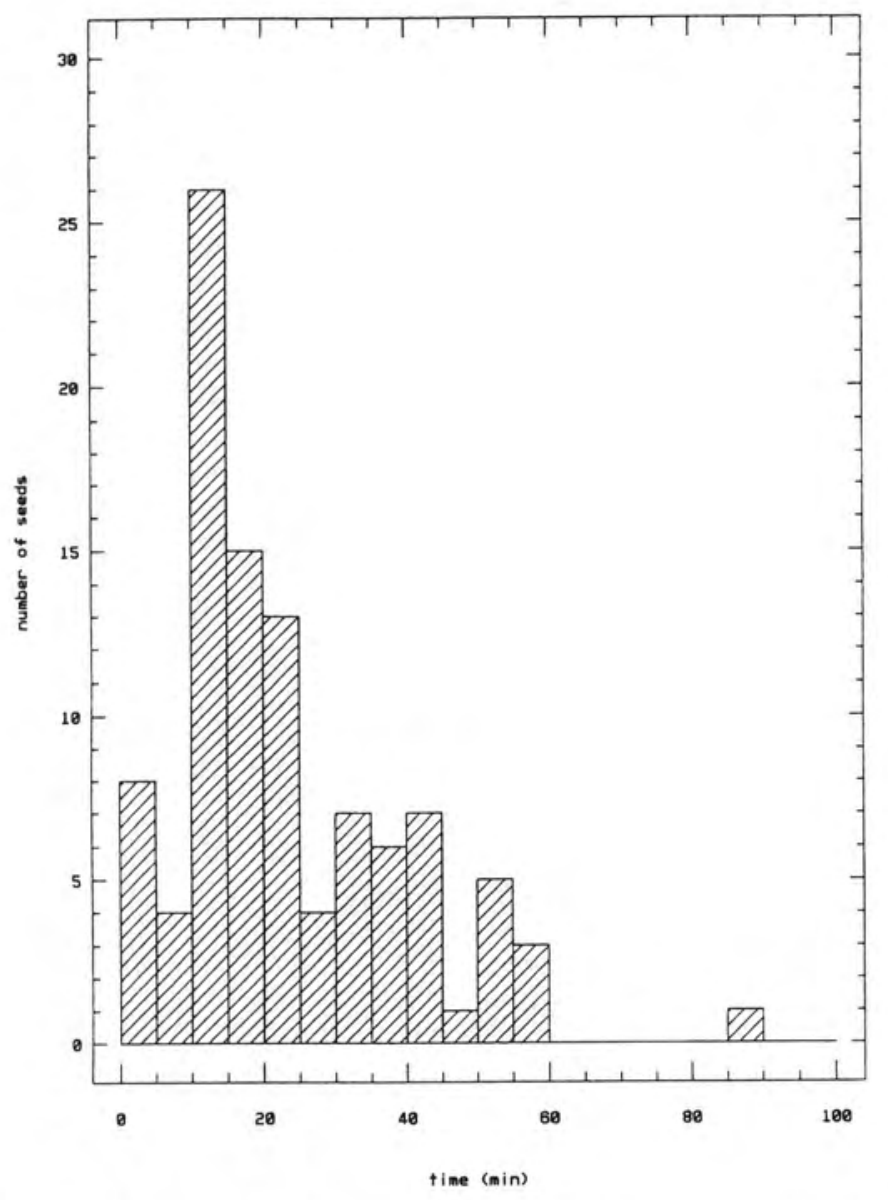

Figure 7. Frequency histogram of seeds of $M$. annua removed by ants $(\mathrm{N}=100)$. The seeds were collected in a mean time of 24.4 minutes. Almost all the seeds were removed by 60 minutes

sing distance; followed by a much less steep decrease in the number of seeds (Fig. 5). The distance of dispersal is negatively correlated with the weight of the seed $(r=0.97$, $\mathrm{P}<0.001$ ) (Fig. 6).

The seeds were collected by ants in a mean time of $24.4 \pm 15.8 \mathrm{~min}$ (range 3-90 min), with a modal peak between 10 and 15 min (Fig. 7). Most of the seeds are usually removed within $60 \mathrm{~min}$ (Fig. 7).

Dispersal of seeds by ants is shown in Fig. 8. From a total of 1.500 marked seeds, 544 were removed from where they were placed at the start of the experiment. Of the seeds removed, $95.2 \%(518 / 544)$ were recovered on excavation of the ant nest. The others were found abandoned along the path followed by the ants. The M. апnиa seeds in the nest were intact but without the caruncle. Others seeds, mostly Poaceae and Fabaceae were also present. The maximum and mean distance of $M$. апnиa seeds dispersal by ants were 14 and $3.4 \pm 2.3 \mathrm{~m}$, respectively (Fig. 8). Beyond $6 \mathrm{~m}$ the number of seeds collected was considerably reduced (Fig. 8).

Comparison of the data for autochorous and myrmecochorous dispersal shows that the mean distance achieved by diplochory was $<5 \mathrm{~m}$ (Figs 5 and 8 ).

\section{DISCUSSION}

\section{Fruit and seed structure}

The fruit wall of $M$. апnиa consists of photosynthetic parenchyma and a mechanical layer as in other Euphorbiaceae (Chadefaud and Emberger 1960). The mechanical layer, how-

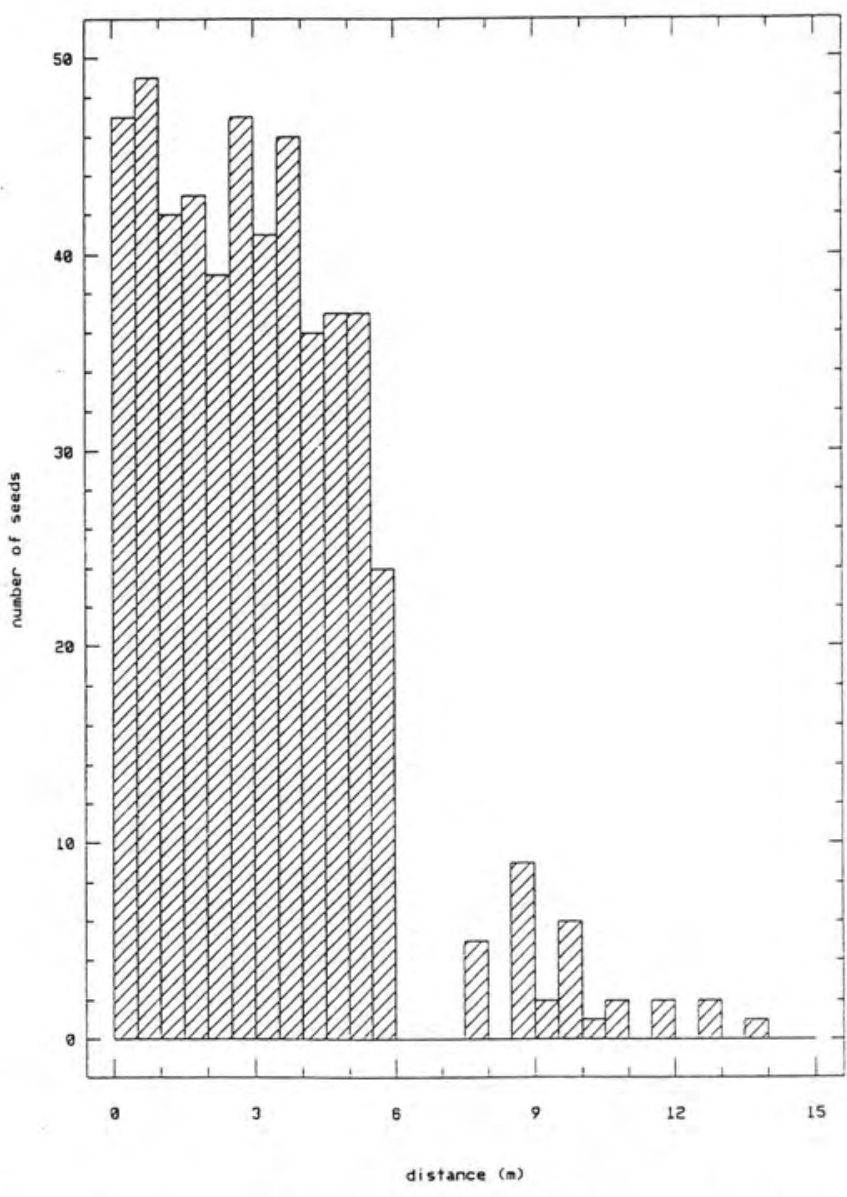

Figure 8. Frequency histogram of distance of $M$. anfnia seed dispersal by ants $(\mathrm{N}=518)$. The mean distance was $3.4 \mathrm{~m}$ with a modal peak between 0.5 and $1 \mathrm{~m}$. Few seeds are dispersed beyond $6 \mathrm{~m}$.

ever, may vary in complexity, in the sense that it may be responsible for the explosive dehiscence of the seeds, as in $\mathrm{Se}$ bastiania klotzschiana Meull. Arg. (Burkart 1951) and some species of the genus Euphorbia (Berg 1990), or for simple opening of the capsule (Fahn and Werker 1972). The turning inside-out of the mechanical layer in M. аппиа is due to the different layers of cells and the folding of the mechanical layer in the chalazal area. This different orientation of the cells gives rise to tension on dehydration, causing opening of the capsule along the dehiscence lines. As soon as the capsule opens, the inner epithelial layer of the mechanical layer continues to dehydrate, contracting and turning inside-out. The particular disposition of the mechanical layer in the chalazal region is affected by this torsion and forcibly ejects the seeds.

Seed structure is also similar to that in other species of Euphorbiaceae (Boesewinkel and Bouman 1984), all of which have a caruncle. The thick layer of Malpighian-like cells with heavily lignified and suberized walls ensures a hard seed coat. The absence of a cuticle on the caruncle favours local absorption of water which diffuses into the outer integument from where it cannot escape because of the cuticle. This may provide a water reserve during germination (Bianchini and Pacini 1996, Lisci and al. 1996a).

\section{Seed dispersal}

Polychory is common in plants in combinations such as autochory - myrmecochory, e.q. Viola spp. (Beattie and Lyons 1975), ornithochory - myrmecochory, e.q. Miconia spp. (Byrne and Levey 1993) or autochory - ornithochory - myr- 
mecochory, e.q. Petalostigma pubescens Domin (Clifford and Monteith 1989). The seeds of $M$. annua are dispersed in twosteps, first by autochory and subsequently by ants, however the distances achieved in the first stage are modest and related to seed weight. The distribution curve obtained is in line with the spatial distributions of seeds of other autochorous plants (Willson 1993). Autochory only permits the seed to be expelled from the capsule reaching short distances of dispersal, but may be important in propelling the seeds away from the parent plant (Roberts and Haynes 1983). The fact that the seeds of the same capsule are launched in different directions might mean that sibling seeds are initially separated and do not compete with each other (Willson and al. 1987). According to Beattie and Lyons (1975), autochory may be viewed as a device to escape seed predators in space by scattering seeds prior to ant dispersal. Explosive fruits are themselves regarded by Janzen (1971) as a device to avoid predator concentration at the source of the seed crop.

As for most myrmecochorous species (Beattie and Lyons 1975, Culver and Beattie 1978, Higashi and al. 1989, Gibson 1993 a), the mean distance of dispersal of the seeds of $M$. annua by ants is short $(3.4 \mathrm{~m})$. Our results show, however, that the seeds are quickly removed from the ground and carried away to the nest. Few seeds were found abandoned along the ant paths. By their rapid removal, seeds may avoid predation (O’Dowd and Hay 1980, Berg 1981, Heithaus 1981, Turnbull and Culver 1983, Slingsby and Bond 1985, Ohara and Higashi 1987, Hughes and Westoby 1990, Hughes 1991, Westoby and al. 1991, Gibson 1993b). In fact, Janzen (1969) claims that the presence of important seed predators would lead to the selection of traits favouring dispersal agents that remove the seeds rapidly after maturation. The combination of autochory and myrmecochory to remove expelled seeds to nests for conservation, and possibly for impregnation with repellents (Janzen 1969), is well suited to achieve this end (Berg 1975). In some cases, the seeds may be placed in microsites of the ant nest that favour germination (Beattie and Culver 1983, Hanzawa and al. 1988; Danin and Yom-Tov 1990), and/or protection from fre (Hughes and Westoby 1990, Hughes 1991, Westoby and al. 1991, Gibson 1993a). Seeds buried by ants might be important for myrmecochorous species to ensure the presence of seed banks in the soil (Bond and Slingsby 1983, Kjellsson 1985b, Thompson 1987). According to Ohtsuka and Ohsawa (1994), some therophytic communities are maintained by seed banks buried in soils, which are periodically cut or ploughed. Cavers and Benoit (1989) report that in arable land, seed banks derived from annual weeds growing on the land and wind-dispersed weed seeds are not common. Thus, seed bank annuals are not invasive pioneers but are weeds adapted to man-made habitats exposed to frequent disturbances (Baker 1974, Holzner 1977).

$M$. annua is an annual weed that occurs in cultivated fields where the soil is frequently ploughed. This suggests that the relatively short-distance dispersal of $M$. annua seeds by myrmecochory is sufficient to get the seeds underground where they can germinate when the field is ploughed. Ploughing makes year-round germination possible (Pacini 1990). In this way, $M$. апnиa, a species capable of completing its life-cycle between ploughings, creates and maintains seed banks in the soil. As pointed out by Ohtsuka and Ohsawa (1994), this property offers competitive advantage over perennials that may invade a site but are unable to reach the reproductive phase due to recurrent ploughing.

\section{ACKNOWLEDGEMENTS}

This research was supported by a grant from the Ministero dell 'Universita e della Ricerca Scientifica e Tecnologica (M. U. R. S. T.), Italy. We thank F. CIAMPOLINI for technical assistance; we are gratefulalso to Dr. B. M. Parkinson for helpful comments and linguistic improvement of the manuscript.

\section{LITERATURE CITED}

ANDERSEN A. N., 1988. Dispersal distance as a benefit of myrmecochory. Oecologia 75: 507-511

ANDERSEN A. N., 1991. Seed harvesting by ants in Australia. In: Ant - Plant Interactions. Huxley C. R., Cutler D. F. (eds.), Oxford University Press, Oxford, pp 493-503

ARONNE G., WII., COCK C. C., 1994. First evidence of myrmecochory in fleshy-fruited shrubs of the Mediterranean region. New Phytologist 127: 781-788

BAKER H. G., 1974. The evolution of weeds. Annual Review of Ecology and Systematics 5: 1-24

BEATTIE A. J., 1985. The Evolutionary Ecology of Ant-Plant Mutualism. Cambridge University Press, Cambridge

BEATTIE A. J., LYONS N., 1975. Seed dispersal in Viola (Violaceae): adaptations and strategies. American Journal ofBotany 62: 714-722

BEATTIE A. J., CULVER D. C., 1981. The guild of myrmecochores in the herbaceous flora of West Virginia forests. Ecology 62: 107115

BEATTIE A. J., CULVER D. C., 1983. The nest chemistry oftwo seed-dispersing ant species. Oecologia 56: 99-103

BERG R. Y., 1975. Myrmecochorous plants in Australia and their dispersal by ants Australian Journal of Botany 23: 475-508

BERG R. Y., 1981. The role of ants in seed dispersal in Australian lowland heathland. In Ecosystems of the World, Heathlands and Related Shrublands. Specht R. L. (ed.), Elsevier, Amsterdam, pp. 51-59

BERG R. Y., 1990. Seed dispersal relative to population structure, reproductive capacity, seed predation, and distribution in Euphorbia balsamifera (Euphorbiaceae), with a note on sclerendochory. Sommerfeltia 11: 35-63

BIANCHINI M., PACINI E., 1996. The caruncle of Ricinus communis L. (castor bean): its development and role in seed dehydration, rehydration, and germination. International Journal Plant Science 157: 40-48

BOESEWINKEL F. D., BOLMAN F., 1984. The seed: structure. In: Embryology of Angiosperms. Johri B. M. (ed.), Springer-Verlag, Berlin, pp. 567-610

BOND W. J., SLINGSBY P., 1983. Seed dispersal by ants in shrublands of the Cape Province and its evolutionary implications. South Africa Journal of Science 79: 231-233

BOND W. J., YEATON R., STOCK W. D., 1991. Myrmecochory in Cape fynbos. In Ant - Plant Interactions. Huxley C. R., Cutler D. F. (eds.), Oxford University Press, Oxford, pp. 448-462

BUCKLEY R. C., 1982. Ant-plant interactions: a world review. In: Ant - Plant Interactions in Australia. Buckley R. C. (ed.), Junk, The Hague, Geobotany 4, pp. 111-141.

BLURZKART A., 1951. Un arbol "artillero" y mirmecófilo de la flora argentina, del genero "Sebastrania". Darwiniana 9: 614

BYRNE M. M., LEVEY D. J., 1993. Removal of seeds from frugivore defecations by ants in a Costa Rican rain forest. In: Frugivory and Seed Dispersal: Ecological and Evolutionary Aspects. Fleming T. H., Estrada A. (eds.), Kluwer Academic Publishers, Dordrecht, Vegetatio $107 / 108$, pp. 363-374

CAVERS P. B., BENOIT D. L., 1989. Seed banks in arable land. In: Ecology ofsoil seed banks. Leck M. A., Parker V. T., Simpson R. L. (eds.), Academic Press, San Diego, pp. 309-328

CHADEFAUD M., EMBERGER L., 1960. Traite de Botanique. Masson et $\mathrm{Co}$, Paris 
CHARPIN J., SURINYACH R., (eds.), 1974. Atlas Europeen des pollens allergissants Sandoz Editions, Paris

CLIFFORD H. T., MONTEITH G. B., 1989. A three phase seed dispersal mechanism in Australian quinine bush (Petalostigma pzubescenrs Domin). Biotropica 21: 284-286

COWLING R. M., PIERCE S. M., STOCK W. D., COCKS M., 1994. Why are there so many myrmecochorous species in the Cape fynbos? In: Plant-Animal Interactions in Mediterranean-Type Ecosystems. Arianoutsou M., Groves R. H. (eds.), Kluwer Academic Publishers, The Netherlands, pp. 159-168.

CULVER D. C., BEATTIE A. J., 1978. Myrmecochory in Viola: dynamics of seed-ant interactions in some West Virginia species. Journal of Ecology 66: 53-72.

CULVER D. C., BEATTIE A. J., 1980. The fate of Viola seeds dispersed by ants American Journal of Botany 67: 710-714

DANIN A., YOM-TOV Y., 1990. Ant nest as primary habitats of Silybum marranum (Compositae). Plant Systematics and Evolution 169: 209-217

DAVIDSON D. W., MORTON S. R., 1981. Myrmecochory in some plants (F. Chenopodiaceae) ofthe Australian arid zone. Oecologia 50: 357-366

DURAND B., DURAND R., 1991. Sex determination and reproductive organ differentiation in Mercurialis. Plant Science 80: 49-65

DURAND R., DURAND B., 198 5. Mercurialis. In: Handbook of Flowering. Halevy H. A. (ed.), CRC Press Boca Raton, Florida, pp. 376-387

FAHN A., WERKER E., 1972. Anatomical mechanisms of seed dispersal. In: Seed Biology. Kozlowski T. T. (ed.), Academic Press, New York, pp. 151-221

GABAY R., PLITMANN U., DANIN A., 1994. Factors affecting the dominance of Silybum marianum L. (Asteraceae) in its specific habitats. Flora 189: 201-206

GIBSON W., 1993a. Selective advantages to hemi-parasitic annuals, genus Melampyrum, of a seed-dispersal mutualism involving ants: I. Favorable nest sites. Oikos 67: 334-344.

GIBSON W., 1993b. Selective advantages to hemi-parasitic annuals, genus Melampyrum, of a seed-dispersal mutualism involving ants: II. Seed-predator avoidance. Oikos 67: 345-350

HANDEL S. N., 1978. The competitive relationship of three woodland sedges, and its bearing on the evolution of ant dispersal of Carex pedunculata. Evolution 32: 151-163.

HANZAWA F. M., BEATTIE A. J., CULVER D. C., 1988. Directed dispersal demographic analysis of an ant-seed mutualism. American Naturalist 131: 1-13.

HEITHAUS E. R., 1981. Seed predation by rodents on three ant-dispersed plants. Ecology 62: 136-145

HESLOP-HARRISON Y., 1977. The pollen-stigma interaction: pollen tube penetration in Crocus. Annals of Botany 41: 913-922

HIGASHI S., TSUYUZAKI S., OHARA M., ITO F., 1989. Adaptive advantages of ant-dispersed seeds in the myrmecochorous plant Trillizum tschonoskii (Liliaceae) Oikos 54: 389-394

HOLZNER W., 1977. Weed species and weed communities. Vegetatio 38: $13-20$

HOWE H. F., SMALLWOOD J., 1982. Ecology of seed dispersal. Annual Review of Ecology and Systematics 13: 201-228

HUGHES L., 1991. The relocation ofant nest entrances: potential consequences for ant-dispersed seeds. Australian Journal of Ecology 16: 204-214

HUGHES L., WESTOBY M., 1990. Removal rates of seeds adapted for dispersal by ants. Ecology 71: 138-148.

HUGHES L., WESTOBY M., JOHNSON A. D., 1993. Nutrient costs ofvertebrate- and ant-dispersed fruits. Functional Ecology 7: 54-62

JANZEN D. H., 1969. Seed-eaters versus seed size, number, toxicity and dispersal Evolution 23: 1-27.

JANZEN D. H., 1971. Seed predation by animals. Annual Review of Ecology and Systematics 2: 465-492

JENSEN W. A., 1962. Botanical Histochemistry. Freeman W. H. and Co, San Francisco

KJELLSSON G., 1985a. Seed fate in a population of Carex pilulifera L. I. Seed dispersal and ant-seed mutualism. Oecologia 67: 416-423
KJELLSSON G., 1985b. Seed fate in a population of Carex pilulifera L. II. Seed predation and its consequences for dispersal and seed bank. Oecologia 67: 424-429.

LISCI M., PACINI E., 1993. Plants growing on the walls of Italian towns. 2 Reproductive ecology. Giornale Botanico Italiano 127: 1053-1078

LISCI M., TANDA C., PACINI E., 1994. Pollination ecophysiology of Mercurialis annua L. (Euphorbiaceae), an anemophilous species flowering all year round Annals of Botany 74: 125-135

LISCI M., BIANCHINI M., PACINI E., 1996a. Structure and function ofthe elaiosome in some angiosperm species. Flora 191: 131-141

LISCI M., CARDINALI G., PACINI E., 1996b. Pollen dispersal and role ofpollenkitt in Mercurialis annua L. (Euphorbiaceae). Flora 191: 385-391

LOUIS J. P., AUGLUR C., TELLER G., 1990. Cytokinins and differentiation processes in Mercurialis annua. Plant Physiology 94: 1535-1541

MEUSEL H., JAGER E., RAUSCHERT S., WEINERT E., 1978. Vergleichende Chorologie der zentraleuropaischen Flora. Fischer Verlag, Jena.

MILEWSKI A. V., BOND W. J., 1982. Convergence ofmyrmecochory in mediterranean Australia and South Africa. In: Ant - Plant Interactions in Australia. Buckley R. C (ed.), Junk, The Hague, Geobotany 4, pp. 89-98

NAKANISHI H., 1994. Myrmecochorous adaptations of Corydalis species (Papaveraceae) in southem Japan. Ecological Research 9: 1-8

O'BRIEN T. P., MCCULLY M. E., 1981. The Study of Plant Structure Principles and Selected Methods. Termarcarphi, Melbourne

O'DOWD D. J., HAY M. E., 1980. Mutualism between harvester ants and a desert ephemeral: seed escape from rodents. Ecology 61: 531540

OHARA M., HIGASHI S., 1987. Interference by ground beetles with the dispersal by ants of seeds of Trillium species (Liliaceae). Journal of Ecology 75: 1091-1098

OHTSUKA T., OHSAWA M., 1994. Accumulation ofburied seeds and establishment of ruderal therophytic communities in disturbed habitat, Central Japan. Vegetatio 110: 83-96

PACINI E., 1990. Mercurialis annua L. (Euphorbiaceae) seed interactions with the ant Messor structor (Latr.), hymenoptera: Formicidae. Acta Botanica Neerlandica 39: 253-262

PIGNATTI S., 1982. Flora d'Italia. Edagricole, Bologna

PIJL VAN DER L., 1982. Principles of Dispersal in Higher Plants. Springer-Verlag, New York

ROBERTS M. L., HAYNES R. R., 1983. Ballistic seed dispersal in Illicium (Illiciaceae). Plant Systematics and Evolution 143: 227-232

SERNANDER R., 1906. Entwurf einer Monographie der Europaischen Myrmekochoren. Bihang till K. Svenska Vetenskaps akademiens Mandlingar 41: 1-410.

SLINGSBY P., BOND W. J., 1985. The influence of ants on the dispersal distance and seedling recruitment of Leucospermtum conocarpodendron (L.) Buck (Proteaceae) South Africa Journal of Botany 51: 30-34

THOMPSON K., 1987. Seeds and seed banks. New Phytologist 106 [Suppl.): 23-34

TROCKENBRODT M., 1994. Light and electron microscopic investigations on wound reactions in the bark of Salix caprea L. and Tilia tomentosa Moench. Flora 189: 131-140.

TURNBULL C. L., CULVER D. C., 1983. The timing of seed dispersal in Viola nutallii attraction ofdispersers and avoidance ofpredators. Oecologia 59: 360-365

WESTOBY M., RICE B. L., 1981. A note on combining two methods ofdispersal-for-distance. Australian Journal of Ecology 6: 23-27

WESTOBY M., FRENCH K., HUGHES L., RICE B. I, RODGERSON L., 1991. Why do more species use ants for dispersal on infertile compared with fertile soils? Australian Journal of Ecology 16: 445455

WESTOBY M., RICE B. L., SHELLEY J. M., HAIG D., KOHEN J. L., 1982. Plants use of ants for dispersal at West Head, New South Wales. In: Ant - Plant Interactions in Australia. Buckley R. C. (ed.), Junk, The Hague, Geobotany 4, pp. 75-87 
WILLSON M. F., 1993. Dispersal mode, seed shadows, and colonization patterns. In Frugivory and Seed Dispersal: Ecological and Evolutionary Aspects. Fleming T. H., Estrada A. (eds.), Kluwer Academic Publishers, Dordrecht, Vegetatio 107/108, pp. 261-280
WILLSON M. F., HOPPES W. G., GOLDMAN D. A., THOMAS P. A., KATUSIC-MALMBORG P. L., BOTHWELL J. L., 1987. Sibling competition in plants: an experimental study. American Naturalist 129: 304-311

\section{CECHY CHARAKTERYSTYCZNE OWOCÓW I NASION \\ ORAZ ICH ROZSIEWANIE U MERCURIALIS ANNUA L. (EUPHORBIACEAE)}

\section{STRESZCZENIE}

Owoc Mercurialis annua L. stanowi dwunasienną torebkę z ciałkiem mrówczym, małym przydatkiem, który wyrasta z zewnętrznej osłonki w obszarze okienka. Wewnętrzna osłonka posiada grubą warstwę komórek podobnych do komórek Malpighiego, oddzielonych przy okienku przez pozostałość ośrodka zalążka, którego ścianki zawierają subarynę. Brak jest kutykuli osłaniającej ciałko mrówcze, a jego komórki zawierają tłuszcz i białka jako składniki pokarmowe. Rozsiewanie nasion odbywa się przez kombinację autochorii a następnie przez myrmekochorię. Gwałtowne wyrzucanie nasion powodowane jest przez skręcanie mechanicznej warstwy ścian owoców, indukowane jej odwodnieniem. Zjawisko to zależy od różnej orientacji komórek oraz fałdowanie się mechanicznej warstwy w obszarze chalazy. Stwierdzono wyrzucanie nasion na odległość od 1 do $130 \mathrm{~cm}$ (średnia 41,1 cm; modalna 10-20 cm). Na balistyczny rozrzut wpływa waga nasion. Nasiona zbierane były przez mrówki w średnim czasie 24,4 minut a maksymalne i średnie odległości roznoszenia wynosiły odpowiednio 14 i 3,4 m. Spośród transportowanych nasion 95,2\% odnaleziono w gnieździe mrówek. Nasiona w gnieździe były nienaruszone lecz bez ciałek mrówczych. Średnia odległość rozsiewania nasion obydwoma sposobami wynosiła $<5 \mathrm{~m}$. Wszystkie opisane zjawiska dyskutuje się w odniesieniu do możliwych korzyści dla gatunku i adaptacyjnych cech nasion.

SŁOWA KLUCZOWE: mrówki, autochoria, myrmekochoria, ciałko mrówcze, Mercurialis annua, nasiona. 